\title{
Konsumsi Air Minum Dalam Kemasan (AMDK) Pada Mahasiswa
}

\author{
Consumption of Bottled Drinking Water (AMDK) for University Students
}

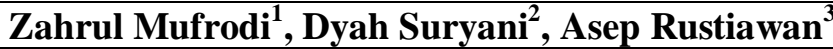

\author{
${ }^{1}$ Program Studi Teknik Kimia, FTI, Universitas Ahmad Dahlan \\ ${ }^{23}$ Program Studi Kesehatan Masyarakat, FKM, Universitas Ahmad Dahlan \\ Email : zahrul.mufrodi@che.uad.ac.id ${ }^{1}$ \\ asep.rustiawan@ikm.uad.ac.id ${ }^{2}$ \\ dyah.suryani@ikm.uad.ac.id ${ }^{3}$
}

\begin{abstract}
Abstrak
Tingginya konsumsi air minum dalam kemasan berkontribusi terhadap masalah lingkungan, termasuk pemborosan air, dan polusi. Masalah lingkungan yang ditimbulkan karena botol plastiknya, pemborosan air minum karena tidak habis diminum, polusi tanah karena keberadaan kemasan air yang tidak bisa terurai tersebut. Tujuan dari penelitian ini adalah untuk mengetahui faktor yang berhubungan dengan konsumsi Air Minum Dalam Kemasan (AMDK) pada mahasiswa dari sisi praktis, kesehatan dan lingkungan. Penelitian ini adalah penelitian observasional analitik dengan pendekatan crossctional dengan melakukan survei online pada mahasiswa dari sebuah universitas swasta di Kota Yogyakarta untuk mengeksplorasi faktor-faktor yang berhubungan dengan konsumsi Air minum dalam kemasan. Responden $(\mathrm{N}=156)$ yang diambil secara acak. Hasil penelitian menyatakan bahwa mahasiswa memilih AMDK dari sisi praktis tidak dipengaruhi oleh jenis kelamin, program studi, jumlah semester yang ditempuh, dan jumlah uang saku. konsumsi AMDK dengan alasan kesehatan dipengaruhi oleh asal program studi ( $p$-value 0.041 ) dan jumlah semester yang ditempuh ( $p$-value 0.002 ). Konsumsi AMDK karena alasan lingkungan dipengaruhi oleh jumlah semester yang telah ditempuh ( $p$-value 0.015$)$ dan status tempat tinggal di Yogyakarta ( $p$-value 0.035).
\end{abstract}

Kata Kunci : Air Minum Dalam Kemasan (AMDK); Praktis; kesehatan; Lingkungan

\section{Abstract}

The high consumption of bottled water contributes to environmental problems, including water waste and pollution. Environmental problems caused by plastic bottles, waste of drinking water because they are not drunk, soil pollution due to the presence of the water that cannot be decomposed. The purpose of this study was to determine the factors associated with consumption of Bottled Drinking Water (AMDK) in students in terms of practical, health and the environment. This study is an observational analytic study with a cross-sectional approach by conducting an online survey of students from a private university in the city of Yogyakarta to explore the factors associated with the consumption of bottled drinking water. Respondents ( $N=156$ ) taken randomly. The results of the study stated that students chose bottled water from the practical side not influenced by gender, study programs, the number of semesters taken, and the amount of pocket money. Consumption of bottled water for health reasons is influenced by the origin of the study program (p-value 0.041) and the number of semesters taken ( $p$-value 0.002). The consumption of bottled water for environmental reasons is influenced by the number of semesters that have been taken ( $p$-value 0.015) and the status of residence in Yogyakarta ( $p$-value 0.035).

Key words : Bottled Drinking Water; practical; health; environment

\section{Pendahuluan}

Akses ke air minum yang aman sangat penting untuk pembangunan manusia. Hal ini sesuai dengan Tujuan Pembangunan Berkelanjutan (SDGs), pada Tujuan ke-6 yaitu untuk memastikan akses ke air minum dan sanitasi yang aman serta terjangkau bagi semua masyarakat pada tahun 2030. ${ }^{1}$ Air minum dalam kemasan (AMDK) mewakili salah satu pasar minuman yang tumbuh paling cepat di dunia dan proyeksi terbaru mengindikasikan bahwa AMDK kemungkinan akan menyalip minuman ringan dan menjadi kategori minuman terbesar berdasarkan volume. Bahkan di negara-negara di mana air ledeng (air sumur) sangat aman, konsumsi air kemasan masih tinggi. Hal ini menimbulkan pertanyaan mengenai mengapa konsumen dengan air ledeng yang sangat aman, dan harganya jauh lebih murah, lebih memilih 
yang lebih mahal dan merusak lingkungan seperti air kemasan.

Data terbaru menunjukkan bahwa konsumsi tahunan AS tahun 2015 adalah 44,3 miliar liter, meningkat lebih dari $47 \%$ dibandingkan dengan konsumsi tahun 2005. Menurut data Biro Pusat Statistik (BPS) konsumsi AMDK masyarakat seluruh Indonesia sebanyak 1.408.148.000 liter, konsumsi ini terus meningkat sampai 2.378.610.000 liter pada tahun 1998, 2.746.216.608 liter pada tahun 1999 dan 3.643.138.000 pada tahun 2000. ${ }^{2}$ Masyarakat semakin banyak memilih untuk mengkonsumsi AMDK dibandingkan air minum biasa karena lebih praktis. ${ }^{3}$

Penelitian sebelumnya menyatakan bahwa peningkatan konsumsi air minum dalam kemasan disebabkan karena kurangnya kepercayaan konsumen akan kualitas air keran/air ledeng. ${ }^{4}$ Penelitian lainnya juga berpendapat bahwa kampanye pemasaran air minum dalam kemasan secara langsung dan tidak langsung menurunkan kepercayaan masyarakat terhadap keran air. ${ }^{5}$ Air kemasan telah meningkatkan kekhawatiran dengan keamanan keran air, sekaligus menciptakan rasa aman palsu dalam air kemasan. Penelitian terdahulu menunjukkan bahwa perilaku konsumsi air dipengaruhi oleh faktor karakteristik masyarakat dan faktor psikologis. ${ }^{6}$ Selain itu faktor seperti kepemilikan rumah, pendapatan yang tinggi, tinggal di daerah perkotaan, keberadaan anak di bawah 5 tahun di rumah tangga dan kenyamanan transportasi air minum kemasan karena kepemilikan mobil berkorelasi dengan konsumsi air minum dalam kemasan yang lebih tinggi. ${ }^{7}$

Daerah Istimewa Yogyakarta disebut sebagai kota pendidikan dengan mahasiswa pada tahun 2015 berjumlah 24.696 orang sedangkan jumlah penduduk Yogyakarta sendiri dengan rentang usia 15-24 yang hanya berjumlah 483 pada tahun 2015 sisanya dapat kita asumsikan sebagai pendatang atau anak perantauan. ${ }^{8}$ Pendatang atau anak perantauan biasanya sangat bergantung pada AMDK sebagai pemenuhan kebutuhan harian, dapat dibayangkan berapa banyak air mineral yang dibutuhkan untuk memenuhi kebutuhan para mahasiswa tersebut.

Berdasarkan latar belakang di atas maka penelitian ini bertujuan untuk mengetahui faktor-faktor yang berhubungan dengan keputusan mahasiswa untuk mengkonsumsi Air Minum Dalam Kemasan (AMDK) di Kota Yogyakarta.

\section{Metode Penelitian}

Jenis penelitian ini adalah penelitian observasional analitik dengan pendekatan crosectional, yaitu peneliti melakukan observasi mengenai perilaku konsumsi Air Minum dalam Kemasan pada mahasiswa dalam satu waktu secara bersamaan. Populasi dalam penelitian ini adalah seluruh mahasiswa pada salah satu universitas swasta di wilayah Kota Yogyakarta. Teknik pengambilan sampel dengan menggunakan non probability sampling dengan jumlah sampel yaitu 156 mahasiswa. Data dikumpulkan dengan menggunakan kuesioner yang terdiri atas karakteristik responden (umur, jenis kelamin, program studi/fakultas, jumlah uang saku, tempat tinggal (kost/tidak), kuesioner memilih AMDK alasan praktis, kuesioner memilih AMDK alasan kesehatan dan kuesioner memilih AMDK alasan lingkungan. Sebelumnya kuesioner telah dilakukan uji validitas dan reliabilitas. Data kemudian dianalisis dengan menggunakan uji chi-square. 


\section{Hasil}

\section{Karakteristik responden}

Hasil penelitian yang dilakukan di salah satu universitas swasta di Kota Yogyakarta didapatkan mahasiswa yang menjadi responden adalah sejumlah 156 mahasiswa dengan karakteristik sebagai berikut :

Tabel 1. Karakteristik responden Mahasiswa dalam pemilihan AMDK

\begin{tabular}{|c|c|c|c|}
\hline \multirow[t]{2}{*}{ No. } & \multirow[t]{2}{*}{$\begin{array}{l}\text { Karakteristik } \\
\text { Responden }\end{array}$} & $\begin{array}{l}\text { Frekuensi } \\
\text { (orang) }\end{array}$ & $\begin{array}{c}\text { Persentas } \\
\text { e }\end{array}$ \\
\hline & & $\mathrm{n}$ & $(\%)$ \\
\hline \multirow[t]{3}{*}{1} & Jenis Kelamin & & \\
\hline & Laki-laki & 37 & 23.7 \\
\hline & Perempuan & 119 & 76.3 \\
\hline \multirow[t]{8}{*}{2} & Umur & & \\
\hline & 17 Tahun & 3 & 1.9 \\
\hline & 18 Tahun & 22 & 14.1 \\
\hline & 19 Tahun & 13 & 8.3 \\
\hline & 20 Tahun & 36 & 23.1 \\
\hline & 21 Tahun & 53 & 34.0 \\
\hline & 22 Tahun & 20 & 12.8 \\
\hline & $\geq 23$ Tahun & 9 & 5.8 \\
\hline \multirow[t]{4}{*}{3} & Program Studi & & \\
\hline & Kesehatan & 73 & 46.8 \\
\hline & Non & 83 & 53.2 \\
\hline & Kesehatan & & \\
\hline \multirow[t]{6}{*}{4} & Semester & & \\
\hline & I & 32 & 20.5 \\
\hline & III & 5 & 3.2 \\
\hline & $\mathrm{V}$ & 36 & 23.1 \\
\hline & VII & 75 & 48.1 \\
\hline & $>$ VII & 8 & 5.1 \\
\hline \multirow[t]{3}{*}{5} & Status Di Jogja & & \\
\hline & Kos & 131 & 83,9 \\
\hline & Tidak Kos & 25 & 16,1 \\
\hline \multirow[t]{3}{*}{6} & Uang Saku & & \\
\hline & $\leq 1.000 .000,00$ & 98 & 62.8 \\
\hline & $>1.000 .000,00$. & 58 & 37.2 \\
\hline & Total & 156 & 100 \\
\hline
\end{tabular}

Berdasarkan Tabel 1 dapat terlihat bahwa mayoritas responden adalah perempuan yang berjumlah 119 orang atau sebesar 76,3\%. Dari 156 responden paling banyak pada usia 21 tahun yaitu sejumlah 53 mahasiswa atau sebesar $34 \%$. Mahasiswa yang yang menjadi responden dalam penelitian ini adalah 83 orang studi di program studi dengan dasar non kesehatan dan sisanya adalah program studi kesehatan. Mayoritas mahasiswa yang menjadi responden adalah semester VII ke atas dan bukan merupakan mahasiswa asli Yogyakarta sehingga mereka mayoritas kost di sekitar kampus yaitu sejumlah 131 orang mahasiswa atau sebesar $83,9 \%$.

\section{Hasil Univariat}

Berdasarkan analisis univariat terhadap hasil jawaban responden dapat terlihat dalam tabel 2 berikut :

\section{Tabel 2. Jumlah Responden yang Mengkonsumsi AMDK}

\begin{tabular}{lcc}
\hline $\begin{array}{l}\text { Karakteristik } \\
\text { Responden }\end{array}$ & $\begin{array}{c}\text { Frekuen } \\
\text { si } \\
\text { (orang) }\end{array}$ & Persentase \\
\cline { 2 - 3 } & $\mathrm{n}$ & $(\%)$ \\
\hline Konsumsi Air & 147 & 94,2 \\
Minum & 9,8 \\
ya & & \\
tidak & & \\
\hline Jumlah AMDK/Botol & & 57,1 \\
1-3 botol/minggu & 89 & 35,2 \\
4-7 botol/minggu & 55 & 6,4 \\
8-12 botol/minggu & 10 & 1,3 \\
13 lebih & 2 & \\
botol/minggu & & \\
\hline Alasan memilih & & \\
AMDK & 87 & 55,8 \\
Praktis & 60 & 38,5 \\
Lupa Membawa & 7 & 4,5 \\
bekal air & 1 & 0,6 \\
Kesehatan & 1 & 0,6 \\
Harga & & \\
Rasa & & 100 \\
\hline Total & 156 & \\
\hline Tabel 2 telihat bahwa dai & 156 mahasisa
\end{tabular}

Tabel 2 terlihat bahwa dari 156 mahasiswa di salah satu universitas swasta di Yogyakarta, hampir semuanya mengonsumsi Air Minum Dalam Kemasan (AMDK) yaitu sejumlah 147 mahasiswa atau sebesar 94,2\%. Dan rata-rata mahasiswa memang hampir setiap hari mengkonsumsi AMDK tersebut. Mayoritas 
responden lebih memilih AMDK karena alasan parktis yaitu sebesar $55,8 \%$ atau sejumlah 87 responden, kemudian diikuti alasan kedua yaitu lupa membawa bekal air yaitu sejumlah 60 responden.

\section{Analisis Bivariat}

Hasil analisis bivariat dengan menggunakan uji chi-square untuk melihat faktor-faktor yang berhubungan dengan perilaku mahasiswa dalam mengkonsumsi AMDK baik dari sisi praktis, kesehatan dan dampak terhadap lingkungan yang dihubungkan dengan karakteristik mahasiswa dapat dilihat dalam Tabel 3 berikut :

Tabel 3: Analisis Bivariat Fakor Yang Berhubungan Dengan Perilaku Mahasiswa Dalam Mengonsumsi Air Minum Dalam Kemasan (AMDK) Dari Sisi Praktis

\begin{tabular}{|c|c|c|c|c|c|}
\hline \multirow{2}{*}{ Variabel } & \multicolumn{2}{|c|}{ Tidak Baik } & \multicolumn{2}{|c|}{ Baik } & \multirow{2}{*}{$p$ value } \\
\hline & $\mathbf{n}$ & $\%$ & $\mathbf{n}$ & $\%$ & \\
\hline $\begin{array}{l}\text { Jenis Kelamin } \\
\text { - Laki-laki } \\
\text { - Perempuan }\end{array}$ & $\begin{array}{l}22 \\
61\end{array}$ & $\begin{array}{l}14.1 \\
39.1\end{array}$ & $\begin{array}{l}15 \\
58\end{array}$ & $\begin{array}{l}9.6 \\
37.2\end{array}$ & 0.494 \\
\hline $\begin{array}{l}\text { Prodi } \\
\text { - Non } \\
\text { Kesehatan } \\
\text { - Kesehatan }\end{array}$ & $\begin{array}{l}48 \\
35 \\
\end{array}$ & $\begin{array}{l}30.8 \\
22.4 \\
\end{array}$ & 40 & $\begin{array}{l}21.2 \\
25.6\end{array}$ & 0.157 \\
\hline $\begin{array}{l}\text { Uang Saku } \\
\bullet<1.000 .000 \\
\bullet \geq 1.000 .000\end{array}$ & $\begin{array}{l}35 \\
48\end{array}$ & $\begin{array}{l}22.4 \\
30.8\end{array}$ & $\begin{array}{l}25 \\
48\end{array}$ & $\begin{array}{l}16.0 \\
30.8\end{array}$ & 0.395 \\
\hline $\begin{array}{l}\text { Semester } \\
\text { - } 1-4 \\
\text { - } 5-8\end{array}$ & $\begin{array}{l}15 \\
68\end{array}$ & $\begin{array}{c}9.6 \\
43.6\end{array}$ & $\begin{array}{l}22 \\
51\end{array}$ & $\begin{array}{l}14.1 \\
32.7\end{array}$ & 0.114 \\
\hline $\begin{array}{l}\text { Status Di } \\
\text { Jogja } \\
\text { • Kos } \\
\text { - Tidak Kos }\end{array}$ & $\begin{array}{l}72 \\
11\end{array}$ & $\begin{array}{c}46.2 \\
7.1\end{array}$ & $\begin{array}{l}59 \\
14\end{array}$ & $\begin{array}{c}37.2 \\
7.0\end{array}$ & 0.431 \\
\hline
\end{tabular}

Berdasarkan Tabel 3 Hasil analisis hubungan antara jenis kelamin dengan pemilihan AMDK karena praktis mempunyai nilai $p$ value 0.494 artinya tidak ada hubungan yang signifikan antara jenis kelamin dengan Perilaku Mahasiswa Dalam Mengonsumsi Air Minum Dalam Kemasan (AMDK) Dari Sisi Praktis.

Hasil analisis hubungan antara program studi responden dengan pemilihan AMDK sisi praktis mempunyai nilai p-value 0.157 artinya tidak ada hubungan yang signifikan antara jenis program studi dengan Perilaku Mahasiswa Dalam Mengonsumsi Air Minum Dalam Kemasan (AMDK) Dari Sisi Praktis.

Tidak ada hubungan antara jumlah uang saku dengan pemilihan AMDK dari sisi praktis dengan nilai p-value 0.395. Hasil analisis hubungan antara jumlah semester yang telah ditempuh dengan pemilihan AMDK dari sisi praktis didapatkan niilai $p$ value 0.114 artinya tidak ada hubungan yang signifikan.

Sedangkan hubungan antara status di Jogja dengan perilaku pemilihan AMDK dari sisi praktis mempunyai nilai p-value 0.431 artinya tidak ada hubungan yang signifikan antara status mahasiwa tinggal di Jogja dengan Perilaku Mahasiswa Dalam Mengonsumsi Air Minum Dalam Kemasan (AMDK) dari Sisi Praktis. Untuk faktor yang berhubungan dengan perilaku mahasiswa dalam mengkonsumsi AMDK dari sisi kesehatan dapat dilihat pada Tabel 4 berikut: 
Tabel 4. Faktor Yang Berhubungan Dengan Perilaku Mahasiswa Dalam Mengonsumsi Air Minum Dalam Kemasan (AMDK) Dari Sisi Kesehatan

\begin{tabular}{|c|c|c|c|c|c|c|c|}
\hline \multirow{2}{*}{ Variabel } & \multicolumn{2}{|c|}{ Tidak Baik } & \multicolumn{2}{|c|}{ Baik } & \multirow{2}{*}{ p value } & \multirow{2}{*}{$\begin{array}{c}\mathbf{R P} \\
(\mathbf{9 5 \%})\end{array}$} & \multirow{2}{*}{ CI } \\
\hline & $\mathbf{n}$ & $\%$ & $\mathbf{n}$ & $\%$ & & & \\
\hline \multicolumn{8}{|l|}{ Jenis Kelamin } \\
\hline - Laki-laki & 25 & 16.0 & 12 & 97.7 & 0.143 & & \\
\hline - Perempuan & 62 & 39.7 & 57 & 36.5 & & & \\
\hline \multicolumn{8}{|l|}{ Prodi } \\
\hline Non Kesehatan & 52 & 33.3 & 29 & 18.6 & 0.041 & 0.488 & $0.257-0.927$ \\
\hline - Kesehatan & 35 & 22.4 & 40 & 26.4 & & & \\
\hline \multicolumn{8}{|l|}{ Uang Saku } \\
\hline$\bullet \quad>1.000 .000$ & 35 & 22.4 & 25 & 16.0 & 0.731 & & \\
\hline - $>=1.000 .000$ & 52 & 33.4 & 44 & 28.2 & & & \\
\hline \multicolumn{8}{|l|}{ Semester } \\
\hline - $1-4$ & 12 & 7.7 & 25 & 16.0 & 0.002 & 0.282 & $0.129-0.616$ \\
\hline - $5-8$ & 75 & 48.1 & 44 & 28.2 & & & \\
\hline \multicolumn{8}{|l|}{ Status Di Jogja } \\
\hline - Kos & 73 & 47.0 & 58 & 37.2 & 1.000 & & \\
\hline - Tidak Kos & 14 & 9.0 & 11 & 7.0 & & & \\
\hline
\end{tabular}

Tabel 4. memperlihatkan hasil analisis hubungan antara jenis kelamin dengan pemilihan konsumsi AMDK dari sisi kesehatan dengan nilai $p$-value 0.143 artinya tidak ada hubungan yang signifikan antara jenis kelamin dengan Perilaku Mahasiswa Dalam Mengonsumsi Air Minum Dalam Kemasan (AMDK) dari Sisi Kesehatan.

Ada hubungan yang signifikan antara asal program studi mahasiswa dengan Perilaku Mahasiswa Dalam Mengonsumsi Air Minum Dalam Kemasan (AMDK) Dari Sisi Kesehatan. Nilai RP 0.488 artinya, mahasiswa yang berasal dari prodi non kesehatan memiliki perilaku 0.488 kali tidak baik tetang perilaku konsumsi AMDK dari sisi kesehatan dibandingkan dengan mahasiwa yang berasal dari prodi kesehatan.

Sedangkan tidak ada hubungan yang signifikan antara besar uang saku dengan Perilaku Mahasiswa Dalam Mengonsumsi Air Minum Dalam Kemasan (AMDK) Dari Sisi Kesehatan dengan nilai p-value 0.731 . Hasil analisis hubungan antara semester yang telah ditempuh Perilaku Mahasiswa Dalam Mengonsumsi Air Minum Dalam Kemasan (AMDK) Dari Sisi Kesehatan yaitu sebanyak nilai $p$-value 0.002 artinya ada hubungan yang signifikan antara semester mahasiwa dengan Perilaku Mahasiswa Dalam Mengonsumsi Air Minum Dalam Kemasan (AMDK) Dari Sisi Kesehatan. Nilai RP 0.282 artinya, mahasiswa yang berasal dari semester 1-4 memiliki perilaku 0.282 kali tidak baik tentang perilaku memilih konsumsi AMDK dari sisi kesehatan dibandingkan dengan mahasiwa yang berasal dari semester 5-8.

Hasil analisis hubungan antara status mahasiswa tinggal di Jogja dengan perilaku memilih konsumsi AMDK dari sisi kesehatan mempunyai nilai $p$-value 1.000 yang berarti tidak ada hubungan yang signifikan. Terkait faktor yang berhubungan dengan perilaku mahasiswa dalam mengkonsumsi AMDK dari sisi lingkungan dapat dilihat pada Tabel 5 berikut ini. 
Tabel 5. Faktor Yang Berhubungan Dengan Perilaku Mahasiswa Dalam Mengonsumsi Air Minum Dalam Kemasana (AMDK) Dari Sisi Lingkungan

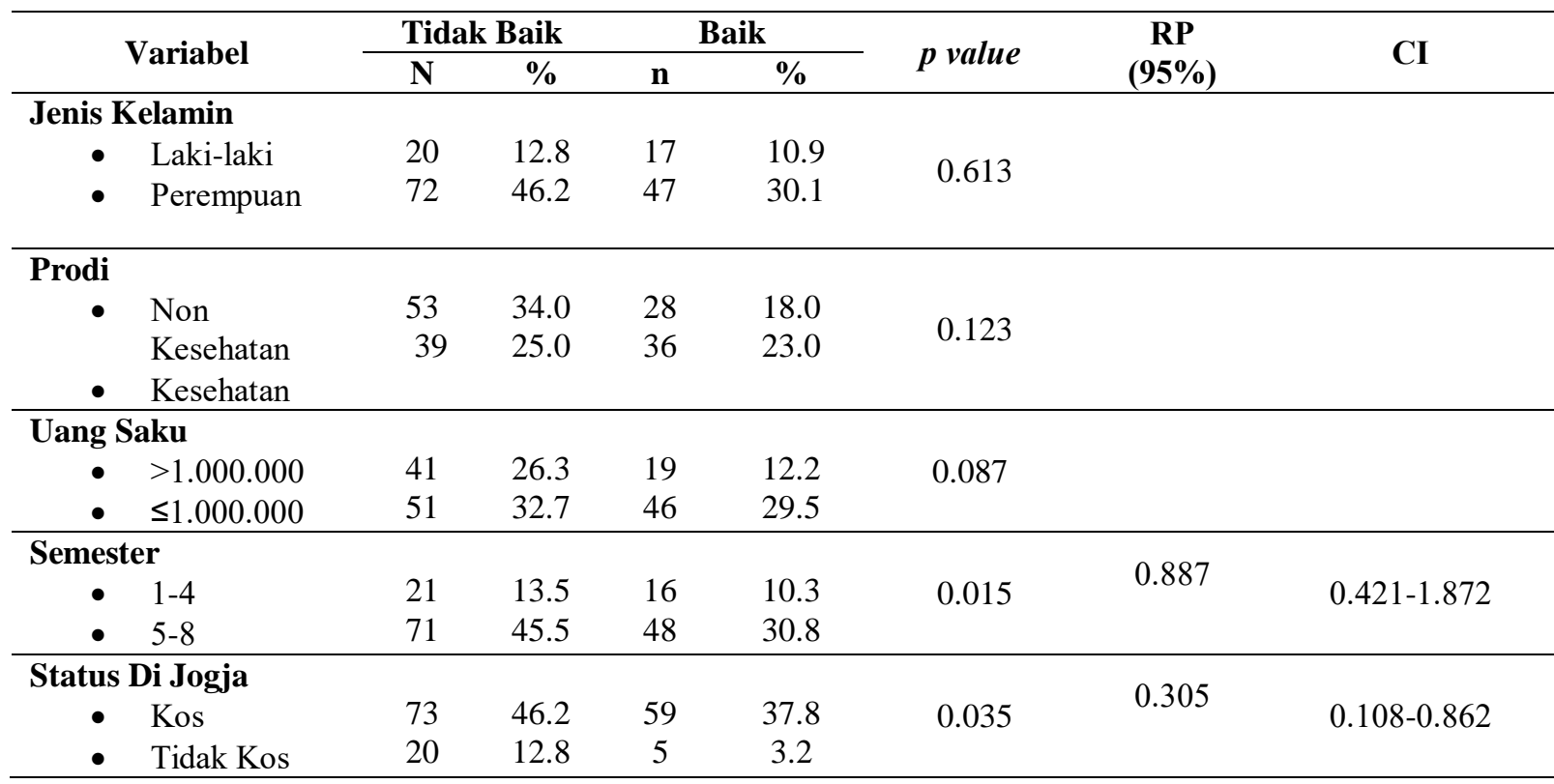

Berdasarkan Tabel 5. Hasil analisis hubungan antara jenis kelamin mahasiswa dengan pemilihan AMDK dari sisi lingkungan mempunyai p-value 0.613 artinya tidak ada hubungan yang signifikan. Tidak ada hubungan antara asal program studi mahasiswa dengan perilaku pemilihan AMDK dari sisi lingkungan dengan nilai $p$ value 0.123 .

Tidak ada hubungan yang signifikan antara besar uang saku mahasiswa dengan Perilaku Mahasiswa Dalam Mengonsumsi Air Minum Dalam Kemasan (AMDK) Dari Sisi Lingkungan dengan nilai $\mathrm{p}=0.087$. Ada hubungan yang signifikan antara jumlah semester yang telah ditempuh mahasiwa dengan Perilaku Mahasiswa Dalam Mengonsumsi Air Minum Dalam Kemasan (AMDK) Dari Sisi Lingkungan dengan $p$ value 0.015 . Nilai RP 0.887 artinya, mahasiswa yang berasal dari semester 1-4 memiliki perilaku 0.887 kali tidak baik dalam pemilihan AMDK dari sisi lingkungan dibandingkan dengan mahasiwa yang berasal dari semester 5-8.
Ada hubungan yang signifikan antara status mahasiswa tinggal di Jogjakarta dengan Perilaku Mahasiswa Dalam Mengonsumsi Air Minum Dalam Kemasan (AMDK) Dari Sisi Lingkungan ( $p$-value $0.015)$. Nilai RP 0.305 artinya, mahasiswa yang berstatus kos di Yogyakarta memiliki perilaku 0.305 kali tidak baik dalam pemilihan konsumsi AMDK dari sisi lingkungan dibandingkan dengan mahasiwa yang tidak kost.

\section{Pembahasan}

Air sangatlah penting bagi tubuh manusia. Hal ini dikarenakan $70 \%$ dari tubuh kita adalah air. Saat melakukan kegiatan seharihari, terutama di luar ruangan, tentu banyak mengonsumsi air minum untuk memenuhi kebutuhan tubuh. Apalagi seorang mahasiswa yang sangat padat kegiatan, memilih menggunakan Air minum dalam kemasan (AMDK) merupakan suatu pilihan yang mudah.

Air minum dalam kemasan memang sangat praktis dan mudah dibawa ke mana 
saja. Dalam penelitian ini ternyata hampir semua responden memilih mengkonsumsi air minum dalam kemasan (AMDK) dengan alasan adalah praktis. Mahasiswa lebih memilih AMDK karena tidak perlu bersusah payah membawa air dalam botol khusus dari rumah. Padahal dengan memilih menggunakan AMDK sama halnya melakukan dua kesalahan besar yaitu konsumsi berlebih dan pencemaran lingkungan. Berdasarkan analisis bivariat dari sisi praktis terlihat bahwa konsumsi AMDK pada mahasiswa tidak berhubungan dengan karakteristiknya baik dari jenis kelamin, program studi, semester, uang saku maupun jumlah semester yang sudah ditempuh. Artinya memang AMDK merupakan suatu pilihan yang mudah bagi mahasiswa di sela-sela kesibukannya.

Kecenderungan peningkatan konsumsi botol air merupakan perubahan dalam cara hidup. Ini juga menunjukkan bahwa perkembangan urbanisasi yang luar biasa, kualitas air keran/sumur yang memburuk, tetapi pada saat yang sama, standar hidup yang terus meningkat memungkinkan orang untuk membawa pulang botol air yang mahal. ${ }^{9}$ Studi lain juga mengungkapkan bahwa, orang dengan pendapatan yang relatif tinggi pada siswa atau orang muda lainnya (16-25 tahun) adalah pengguna air kemasan yang paling sering, karena mereka dianggap lebih sensitif terhadap iklan yang tampaknya diterima secara sosial. $^{10}$

Penelitian sebelumnya menyatakan bahwa kebanyakan orang memegang kepercayaan kesehatan tentang air kemasan, tetapi dalam sebagian besar kasus keyakinan kesehatan ini bukan faktor pendorong kuat untuk membeli air minum kemasan. Faktor-faktor lain seperti kenyamanan, biaya dan rasa muncul sebagai alasan yang jauh lebih penting bagi preferensi air minum dalam kemasan. ${ }^{9}$ Selain itu, sebagian besar peserta merasa bahwa tidak ada manfaat kesehatan yang signifikan dalam minum air kemasan dibandingkan dengan air ledeng. Penelitian terdahulu menyatakan bahwa alasan utama mengonsumsi air minum kemasan di antara penduduk Nairobi adalah aman dan manfaat kesehatan. ${ }^{11}$ Hal ini juga tidak berbeda dengan penelitian lain yang menunjukkan ada hubungan antara konsumsi air kemasan dengan gaya hidup sehat. ${ }^{12}$ Di Eropa dan bahkan negara lainnya banyak konsumen percaya bahwa mineral alami air memiliki sifat obat atau menawarkan manfaat kesehatan lainnya. ${ }^{13}$

Berdasarkan konsumsi AMDK dari sisi kesehatan didapatkan hasil bahwa asal program studi mahasiswa berhubungan dengan pemilihan AMDK sebagai sumber air minum mahasiswa dengan nilai $p$-value 0.041 . Hal ini dimungkinkan karena responden dengan prodi kesehatan kemungkinan banyak mendapatkan informasi tentang kelebihan dan kekurangan kualitas AMDK dibanding air keran/air sumur di Indonesia. Menurut penelitian sebelumnya yang menyatakan bahwa responden yang berpendidikan lebih rendah cenderung berpikir bahwa air kemasan lebih aman, dan persepsi bahwa air botolan lebih aman memiliki efek independen dan negatif terhadap konsumsi air keran. ${ }^{14}$

Kurangnya air minum yang aman dan mudah diakses, sering dihadapi di negaranegara berkembang, dan meningkatnya kekhawatiran tentang efek kesehatan yang terkait dengan komponen berbahaya dalam pasokan air minum di kota telah mendorong tingginya konsumsi air kemasan. Dalam menilai kualitas air minum, konsumen banyak bergantung pada indera perasa dengan hasil bahwa air kemasan dianggap murni, aman, dan rasanya enak, sehingga konsumsi mereka meningkat meskipun harganya sangat tinggi dibandingkan dengan air ledeng. ${ }^{15}$ Negaranegara yang mempunyai kualitas air ledeng yang aman ternyata juga merupakan negaranegara dengan konsumsi air minum dalam kemasan tertinggi. ${ }^{9}$

Sedangkan untuk konsumsi AMDK dari sisi lingkungan didapatkan hasil bahwa jumlah semester yang ditempuh serta status tempat 
tinggal di lokasi studi berhubungan dengan konsumsi AMDK. Hal ini dimungkinkan bahwa mahasiswa yang menempuh semester lebih lama telah mendapatkan lebih banyak informasi tentang dampak konsumsi AMDK terhadap lingkungan. Sedangkan status tempat tinggal menyatakan bahwa mahasiswa asli Yogyakarta atau mempunyai keluarga di Yogyakarta mempunyai usaha untuk menjaga lingkungan di kota ini. Penelitian ini sejalan dengan penelitian sebelumnya yang menyatakan bahwa sebagian besar mahasiswa pascasarjana tidak minum air kemasan, Sesuai dengan perbedaan antara kelompok di Universitas Purdue, ada hubungan negatif yang signifikan antara usia responden dan jumlah air kemasan yang dilaporkan mereka konsumsi ( $\mathrm{r}=-0.132, \mathrm{P} \backslash 0,01)$. Tidak ada perbedaan yang signifikan secara statistik antara sikap pria dan wanita tentang dampak lingkungan dari air minum kemasan ketika botol-botol tersebut didaur ulang. Dengan kata lain, ketika menghitung daur ulang, persepsi wanita tentang dampak lingkungan dari air kemasan sama dengan laki-laki. ${ }^{4}$

Kekhawatiran tentang kesehatan, rasa, dan kualitas air lebih menonjol sementara dampak pada lingkungan menunjukkan korelasi yang lebih rendah dengan konsumsi air kemasan. Hal ini diartikan bahwa konsumen lebih memilih konsumsi AMDK karena kesehatan dan rasa serta mengesampingkan dampak terhadap lingkungan. ${ }^{16}$

Untuk mengurangi dampak konsumsi AMDK yang semakin meningkat setiap harinya, perlu digalakkan kampanye untuk menyadarkan konsumen akan dampak AMDK. Pengurangan penggunaan konsumsi AMDK salah satunya dengan menggunakan kemasan air minum isi ulang. Kesalahpahaman tentang masalah kesehatan, rasa, dan kualitas AMDK harus menjadi yang terdepan dalam pesan komunikasi kampanye ini. Selain itu, lebih banyak upaya perlu diarahkan untuk menyoroti dampak lingkungan negatif yang terkait dengan produksi dan konsumsi air kemasan. Penelitian sebelumnya menyatakan bahwa dampak negatif lingkungan dan sosial yang terkait dengan penggunaan dan konsumsi air kemasan dapat dihindari dengan meminum air keran/air sumur sebagai gantinya.

\section{Kesimpulan}

Berdasarkan penelitian ini dapat disimpulkan bahwa :

1. Mahasiswa mengkonsumi Air Minum Dalam Kemasan (AMDK) disebabkan karena praktis

2. Mahasiswa mengkonsumsi Air Minum Dalam Kemasan (AMDK) dari sisi kesehatan berhubungan dengan jenis program studi dan jumlah semester yang telah ditempuh.

3. Mahasiswa mengkonsumsi Air Minum Dalam Kemasan (AMDK) dari sisi lingkungan berhubungan dengan jumlah semester yang telah ditempuh dan status tempat tinggal di Yogyakarta

\section{Daftar Pustaka}

1. United Nations Official Document. 2015. Retrieved from: http:// www. un. org/ga/search/view_doc.asp?symbol=A/R $\mathrm{ES} / 70 / 1 \&$ Lang $=\mathrm{E}$.

2. Badan Pusat Statistik. 2000. Tingkat Konsumsi Air Minum dalam Kemasan. Badan Pusat Statistik, Jakarta.

3. Widjaja, A., Kunto, W.S. 2014. Analisa Persepsi Konsumen Tentang Atribut Produk AMDK. Jurnal Manajemen Pemasaran Petra. Vol. 2, No. 1, hal: 1-8

4. Saylor, A., Propoky, L., \& Amberg, S. 2011. What's wrong with the tap? Examining perceptions of tap water and bottled water at Purdue University. Environmental Management, 48, 588-601.

5. Ross, V. L., Fielding, K. S., \& Louis, W. R. 2014. Social trust, risk perceptions and public acceptance of recycled water: 
Testing a social-psychological model. Journal of Environmental Management Elsevier Ltd, 137, 61-68.

6. Johnstone, N., \& Serret, Y. 2012. Determinants of bottled and purified water consumption: Results based on an OECD survey. Water Policy, 14, 668-679.

7. Badan Pusat Statistik. 2016. Jumlah penduduk Kabupaten/Kota Yogyakarta. yogyakarta.bps.go.id.

8. Ferrier, C., 2001. Bottled Water: Understanding a Social Phenomenon. Report Commissioned by WWF, April 2001. pp. 1-26

9. Dasinaa, S. and Delina, E. J. P. 2015. Spatial Distribution of Mineral Water Bottle Usage in Batticaloa District: A Case Study. Proceedings of the 4th International Conference, South Eastern University of Sri Lanka.p:2.

10. Ward LA, Cain OL, Mullally RA, Holliday KS, Wernham AG, Baillie PD, et al. Health beliefs about bottled water: a qualitative study. BMC Public Health 2009;9:196

11. Mbagaya, G.M., Mbato, E.L., 2011. Global Journal of Pure And Applied Sciences VolL. 17, No.2 : 149-153

12. Arnold, E., and Larsen, J., 2006. Bottled water: Pouring Resources Down the Drain. Earth Policy Institute. http:// www.earthpolicy.org/updates/2006

13. Schiffman, L.G., and Kunuk, L., 2003. Consumer Behaviour. Pearson Edition, Replica Press Ltd. India.

14. Dupont D, Adamowicz WL, Krupnick A. Differences in water consumption choices in Canada: the role of sociodemographics, experiences, and perceptions of health risks. $J$ Water Health 2010;8(4):671

15. Burlingame, B., 2003. Reflections on water. Journal of Food Composition and Analysis 16, 533-534

16. Linden, S. 2015. Exploring beliefs about bottled water and intentions to reduce Consumption: The dual-effect of social norm activation and persuasive information. Environment and Behavior, 47, 526-550 